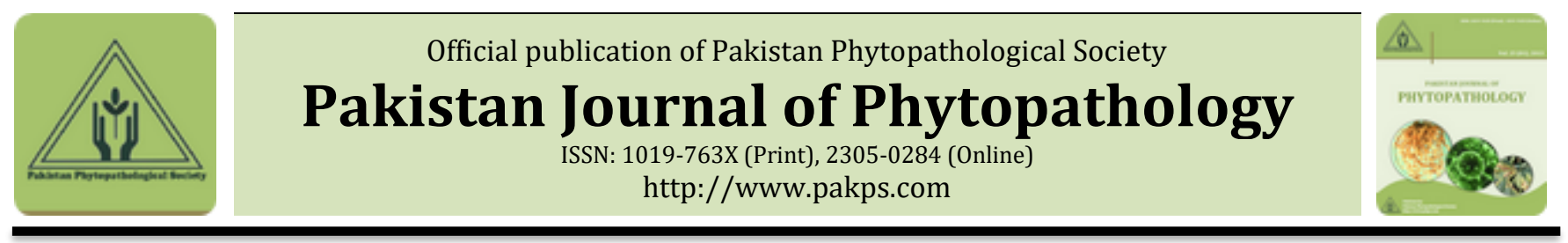

\title{
RESISTANCE DURABILITY OF SEVERAL RICE CULTIVARS AGAINST RICE TUNGRO DISEASE IN SOUTH SULAWESI, INDONESIA
}

\author{
a,b,cNur Rosida*, a,bTutik Kuswinanti, a,bNur Amin, a,bAndi Nasruddin \\ a Department of Plant Pest and Disease, Faculty of Agriculture, Hasanuddin University, Makassar, Indonesia 90245 \\ ${ }^{b}$ Graduate School, Hasanuddin University, Makassar, Indonesia 90245 \\ c Indonesian Rice Tungro Research Center, Lanrang, Sidenreng Rappang, South Sulawesi, Indonesia 91651
}

\begin{abstract}
A B S T R A C T
Tungro disease is one of the main obstacles to rice production in South and Southeast Asia. The cultivation of green leafhopper resistant rice and tungro virus-resistant rice is one of the ways to prevent tungro disease and has been successfully used to control the disease in the tropics. However, some of these varieties have been reported to have lost their resistance due to the adaptation of resistance in green leafhopper population against tungro resistant varieties. Until now, rice varieties that are resistant to green leafhoppers and rice tungro virus which are still frequently used by farmers in South Sulawesi are IR 64, Ciliwung, Inpari 9 Elo, and Inpari 7 Lanrang varieties. Thus, it is necessary to evaluate the durability of these varieties, whether they are still resistant to tungro disease or not. Variety resistance was evaluated by calculating the reduction in plant height (\%), percentage of rice tungro virus infection (\%) and detection of the presence of rice tungro virus using a PCR analysis for RTBV and an RT-PCR for RTSV after being inoculated with tungro virus isolates from South Sulawesi. Results showed that all resistant varieties were infected by tungro bacilliform virus (RTBV): 100, 100, 80, and 80\% infections on IR-46, Ciliwung, IR-64, and IR66, respectively. For the RTV-resistant cultivars, only Inpari 9 Elo and Inpari 7 Lanrang were not infected by rice tungro spherical virus (RTSV). Therefore, it is concluded that to prevent transmission of the tungro virus, Inpari 9 Elo and Inpari 7 Lanrang can still be recommended for planting in South Sulawesi.
\end{abstract}

Keywords: Durability, Resistant variety, Tungro Disease.

\section{INTRODUCTION}

Rice tungro disease (RTD) is the most important virus disease of rice (Oryza sativa L.) in South and Southeast Asian countries (Chong et al., 2015). Tungro disease is caused by the simultaneous infection of two types of viruses that are morphologically and genetically different, namely rice tungro bacilliform virus (RTBV) and rice tungro spherical virus (RTSV). These two viruses can only be transmitted by the green leafhoppers (GLH), especially Nephotettix virescens (Distan) in a semi-persistent manner (Hibino et al., 1978; Hull, 1996; Bunawan et al. 2014).

\footnotetext{
Submitted: September 17, 2020

Revised: December 01, 2020

Accepted for Publication: December 09, 2020

* Corresponding Author:

Email: ochilolittungro@gmail.com

(C) 2017 Pak. J. Phytopathol. All rights reserved.
}

Plants infected by both RTBV and RTSV show typical severe symptoms, including leaf colour change from green to yellow or orange, inhibited growth (stunting), incomplete panicle filling, fewer tillers, and decreased seed fertility (Hibino, 1996). Plants infected by RTBV alone show milder symptoms, while plants infected by RTSV only express no visible symptoms (Azzam and Chancellor, 2002).

The cultivation of GLH resistant-rice cultivars has successfully suppressed the vector populations, thus, RTD infections are also satisfactorily reduced. In South Sulawesi, RTD has been successfully controlled by combining the appropriate planting time and rotation of GLH-resistant varieties (Sama et al., 1991). Rice resistance genes to green leafhoppers that have been identified are Glh1, Glh2, Glh3 (Athwal et al., 1971), Glh5 (Siwi and Khush, 1977), recessive gene glh4 (Siwi and Khush, 1977), Glh6, and Glh7 (Rezaul Karim and Pathak, 
1982), recessive gene glh8 (Ghani and Khush, 1999), Glh9, recessive gene glh10, Glh11, Glh12, and Glh13 (Angeles and Khush, 2000), and Glh14 (Sebastian et al., 1996). Among the 14 resistance genes, four genes have been used in Indonesia, namely Glh1, Glh5, Glh6, and glh4 (Widiarta et al., 2004). In addition to the GLHresistant varieties, tungro virus-resistant varieties have also been released and available to farmers. The RTDresistant genes came from the cultivars of Utri Merah, Balimau Putih (Kobayashi et al., 1993; Choi, 2004), and TKM 6 (Azzam et al., 2001). Utri Merah is known to be able to inhibit the development of RTBV particles ( Hibino et al., 1978). In Indonesia, several RTD-resistant varieties have been introduced with different genes, including Tukad Unda, Tukad Balian, Tukad Petanu, Bondoyudo, Kalimas, Inpari 7 Lanrang, Inpari 8, Inpari 9 Elo, Inpari 36 lanrang and Inpari 37 Lanrang (Wahab, et al., 2017). However, some of the resistant cultivars have lost their resistance due to the presence of GLH populations that are able to attack them (Widiarta et al., 2013) and similarly, tungro viruses have also adapted to several tungro- resistant varieties (Widiarta and Pakki, 2015). Resistant varieties select the green GLH population based on their ability to adapt to these resistant varieties. The green leafhoppers adaptable to resistant varieties are capable of transmitting the tungro virus to the cultivars (Widiarta et al., 2014). In resistant varieties, GLH mostly suck plant sap from the xylem tissue, on the other hand, in susceptible varieties, the insect sucks more plant sap from the phloem tissue (Kawabe, 1985). When GLH begins to suck plant sap from the phloem, it means it has adapted to the resistant plants, hence, the success of virus transmission will be even greater (Widiarta et al., 2014).

Currently, several GLH-resistant cultivars IR 64, Ciliwung, Inpari 9, and Inpari 7; and RTD-resistant cultivars Tukad Balian; Tukad Unda, Inpari 9, and Inpari 7 are widely cultivated in South Sulawesi. In this study, we evaluated the durability of the resistance of those cultivars against the GLH and RTD to determine whether

$$
\text { Percent Infection }=\frac{\text { Number of infected plants }}{\text { Number inoculated plants }} \times 100
$$

Varietal reactions to the RTV and GLH are grouped into three categories: susceptible $(>60.0-100 \%$ infection), moderately resistant ( $>30.0-60.0 \%$ infection) and resistant ( $0-30.0 \%$ infection). After evaluation of the reaction to RTV, the second youngest fully developed leaves were taken from they are still resistant to GLH and RTD after they had been cultivated for many years.

\section{MATERIALS AND METHODS}

Plant materials: Four rice cultivars with different resistance genes to GLH, IR 46, Ciliwung, IR 64, and IR 66 and four tungro-resistant cultivars with different resistance genes were tested, namely: Tukad Balian; Tukad Unda, Inpari 9 and Inpari 7; and Taichung Native 1 (TN1) as a susceptible variety (control, no resistant gene).

RTD inoculation: Tungro-infected rice plants cv. TN-1 were used as source of inoculum in this study. The test plants were artificially inoculated using GLH following the methods of Cabautan, et al. (1995) and Azzam et al. (2000). For each cultivar, ten 7-10-day old seedlings were used. The seedlings were individually placed inside of a test tube $(0.75 \mathrm{~cm}$ diam. and $18 \mathrm{~cm}$ height $)$ containing $0.5 \mathrm{ml}$ of water. Adults GLH were allowed to feed on the inoculum source for a 24-h acquisition feeding before two individuals of the GLH were transferred into each of the test tube for a 24-h inoculation feeding. At the end of the inoculation period, the insects were killed using insecticide, then the seedlings were individually planted in 4-liter pots. Ten uninoculated seedlings for each cultivar were also individually planted in pots as control. The cultivar treatments were arranged in completely randomized design. The inoculated plants were maintained in the greenhouse of the Indonesian Rice Tungro Research Station.

Cultivar reaction to RTV: Plant height of the RTVinoculated and non-inoculated plants were measured at 14, 21 and 28 days after inoculation. Reduction of plant height (\%) was also calculated by following the method of Budot et al., (2014) as $100 \times$ [(height of the uninoculated plants (control) - height of the inoculated plants) / height of the uninoculated plants (control)]. While the percent of RTV-infected plant for each cultivar was also evaluated based on the method of Azzam et al., (2000):

each plant for DNA and RNA extraction.

Detection of RTBV and RTSV: To detect the presence of RTV in each test plant, PCR analyses were carried out on the leaf samples at 28 DAI.

DNA extraction: For RTBV detection, the collected leaf samples were extracted for the total genomic 
DNA using the modified CTAB method (Doyle and Doyle, 1990). A total of $0.1 \mathrm{~g}$ of each leaf sample was pulverized using liquid nitrogen before adding $1 \mathrm{ml}$ of CTAB extraction buffer previously incubated at $65^{\circ} \mathrm{C}$ for 30 minutes. The homogenate was added with an equal volume of CIAA (24:1) and centrifuged at $10,000 \mathrm{rpm}$ for 15 minutes. The top aqueous layer was recovered with $2 / 3$ volume of chilled isopropanol at $\left(-20^{\circ} \mathrm{C}\right)$ and the mixture was centrifuged at $12,000 \mathrm{rpm}$ for 10 minutes. The DNA pellets were then washed with $500 \mu \mathrm{L}$ of $70 \%$ ethanol, dried, and resuspended in $50 \mu \mathrm{L}$ deionized water.

RNA extraction and reverse transcription: For RTSV, RNA was extracted using isogenic RNA Extraction Kit (Amersham Pharmacia). A total of 0.1 $\mathrm{g}$ of each leaf sample was crushed in $1 \mathrm{ml}$ of isogenic buffer and incubated at room temperature for 10 minutes. The homogenate was added to an equal volume of CIAA (24: 1) and centrifuged at 12,000 rpm for 10 minutes. The upper aqueous layer was recovered with $4 / 5$ volume of cold isopropanol at ($20^{\circ} \mathrm{C}$ ) and the mixture was centrifuged at $12,000 \mathrm{rpm}$ for $10 \mathrm{~min}$. The DNA pellet was then washed with $100 \mu \mathrm{l}$ of $70 \%$ ethanol, dried and re-suspended in 50 $\mu \mathrm{l}$ of deionized water. The extracted RNA was then converted into cDNA using Fermentas ${ }^{\mathrm{TM}}$ First Strand cDNA Synthesis Kit according to the manufacturer's instructions.

PCR protocols: The PCR conditions and thermal cycling protocols were tested for optimal amplification. The reagent used in PCR analysis for RTBV detection was mega mix blue (MMB) (Microzone Limited) while pureTaq Ready to Go PCR Bead (GE Healthcare) was used for RTSV detection.

The primers used to detect RTBV were a specific pair of primers GCAGAACAGAACTCTAAGGC (F) and GTCTAAGGCTCATGCTGGAT (R) with an amplification target of ORF2 sequences measuring around $430 \mathrm{bp}$. While the primers used for detection of RTSV were a pair of specific primers that amplified the protein envelope region, namely RTSV-F2 (GAAGAAGCCTATCATGTTCGCGT) and RTSV-R2 (CCTCCACGATATTGTACGAGG) with a target product size of $787 \mathrm{bp}$.

The PCR reaction for RTBV detection was prepared with a total volume of 19 containing 161 Mega Mix
Blue (MMB), 1110 M B2F primers, 1110 M B2R primers, and 11 DNA. The amplification process consists of initial denaturation for 5 minutes at $94^{\circ} \mathrm{C}$, followed by 35 amplification cycles, including denaturation of 50 seconds at $94^{\circ} \mathrm{C}$, primary attachment (annealing) for 30 seconds at $50^{\circ} \mathrm{C}$, extension for 1 minute at $72^{\circ} \mathrm{C}$, then for the final cycle stage is added 5 minutes at $72^{\circ} \mathrm{C}$. The PCR reaction for RTSV detection was made with a total volume of $25 \mu \mathrm{L}$ containing $8.5 \mu \mathrm{L}$ ddH2O, $12.5 \mu \mathrm{l}$ DreamTaq Green PCR Master Mix, $1 \mu \mathrm{L} 10 \mu \mathrm{M}$ RTSVF2 primer, $1 \mu \mathrm{L} 10 \mu \mathrm{M}$ RTSV-R2 primer, and $2 \mu \mathrm{l}$ cDNA. The amplification process is preceded by predenaturation for 5 minutes at $94^{\circ} \mathrm{C}$, followed by 34 cycles including the denaturation stage at $94^{\circ} \mathrm{C}$ for 1 minute, primary attachment (annealing) at $50^{\circ} \mathrm{C}$ for 1 minute, synthesis at $72^{\circ} \mathrm{C}$ for 2 minutes, then extension at $72^{\circ} \mathrm{C}$ for 10 minutes. The results of the application were visualized by electrophoresis on $1 \%$ agarose gel (TBE) with ethidium bromide $(0.5 \mathrm{~g} /$ $\mathrm{ml})$ staining for \pm 15 minutes. The results of DNA visualization were documented with a Gel Doc System (Biorad Country). All PCR reactions were made in 3 replications. Negative controls and positive controls were included to rule out falsepositive or false-negative results. The PCR product was sent to Genetics Science Laboratory for DNA sequencing in order to confirm the identity of the amplified product.

\section{DATA ANALYSIS}

Data of plant height, plant height reduction, and percent of RTV transmission were subjected to ANOVA and if a significant difference amongst treatments were detected, the means were separated using a Tukey's test $(P=0.05)$.

\section{RESULTS}

Plant height reduction by RTV: For each cultivar, the heights of the RTV-inoculated and uninoculated plants were compared on 14, 21, and 28 DAI. In general, plant height increased through the observation times. At 28 DAI, for all cultivars, the inoculated plants were significantly shorter than the un-inoculated control plants. However, for the tungro-resistant cultivars, Tukand Balian and Inpari 9 showed no significant differences in plant height between RTV-inonculated non-inoculated plants (Table 1). 
Table 1. Height of RTV-inoculated and RTV-uninoculated (control) plants of several rice varieties.

\begin{tabular}{llccc}
\hline \multirow{2}{*}{ GLH resistant varieties } & \multirow{2}{*}{ Treatment } & \multicolumn{3}{c}{ Plant height (cm) $(\mathrm{X} \pm \mathrm{SE})$} \\
\cline { 2 - 4 } & & $14 \mathrm{DAI}$ & $21 \mathrm{DAI}$ & $28 \mathrm{DAI}$ \\
\hline \multirow{2}{*}{ TN1 (No resistant gene) } & RTV-inoculated & $17.9 \pm 2.4$ & $25.8 \pm 4.2$ & $25.8 \pm 4.2 \mathrm{a}$ \\
& Un-inoculated & $23.0 \pm 0.2$ & $23.5 \pm 0.2$ & $52.2 \pm 0.2 \mathrm{~b}$ \\
\hline \multirow{2}{*}{ IR 46 } & RTV-inoculated & $22.0 \pm 1.2$ & $34.9 \pm 2.8 \mathrm{~b}$ & $34.9 \pm 2.8 \mathrm{a}$ \\
& Un-inoculated & $23.0 \pm 0.9$ & $24.0 \pm 0.3 \mathrm{a}$ & $54.5 \pm 0.2 \mathrm{~b}$ \\
\hline \multirow{2}{*}{ Ciliwung } & RTV-inoculated & $14.5 \pm 2.1 \mathrm{a}$ & $18.5 \pm 3.9 \mathrm{a}$ & $18.5 \pm 3.9 \mathrm{a}$ \\
& Un-inoculated & $28.5 \pm 0.2 \mathrm{~b}$ & $27.0 \pm 0.6 \mathrm{~b}$ & $41.3 \pm 0.2 \mathrm{~b}$ \\
\hline \multirow{2}{*}{ IR 64 } & RTV-inoculated & $21.1 \pm 2.1 \mathrm{a}$ & $34.4 \pm 3.9$ & $34.4 \pm 3.9 \mathrm{a}$ \\
& Un-inoculated & $27.5 \pm 0.2 \mathrm{~b}$ & $28.0 \pm 0.3$ & $45.5 \pm 0.2 \mathrm{~b}$ \\
\hline \multirow{2}{*}{ RTV resistant varieties } & RTV-inoculated & $17.6 \pm 2.3 \mathrm{a}$ & $27.8 \pm 6.5$ & $27.8 \pm 6.5 \mathrm{a}$ \\
& Un-inoculated & $24.0 \pm 0.3 \mathrm{~b}$ & $24.0 \pm 0.3$ & $44.8 \pm 0.2 \mathrm{~b}$ \\
\hline \multirow{2}{*}{ TN1 (No resistant gene) } & Treatment & \multicolumn{3}{c}{$21 \mathrm{DAI}$} \\
& RTV-inoculated & $20.8 \pm 2.9$ & $20.8 \pm 10.8$ & $13.7 \pm 13.7 \mathrm{a}$ \\
& Un-inoculated & $28.0 \pm 0.6$ & $36.0 \pm 0.6$ & $40.5 \pm 0.5 \mathrm{~b}$ \\
\hline T.Balian & RTV-inoculated & $23.6 \pm 4.6$ & $27.7 \pm 6.9$ & $37.5 \pm 11.9$ \\
& Un-inoculated & $27.0 \pm 0.6$ & $36.0 \pm 0.6$ & $50.5 \pm 0.5$ \\
\hline T.Unda & RTV-inoculated & $19.0 \pm 0.6 \mathrm{a}$ & $15.8 \pm 1.8 \mathrm{a}$ & $21.0 \pm 1.5 \mathrm{a}$ \\
& Un-inoculated & $28.4 \pm 0.5 \mathrm{~b}$ & $35.0 \pm 0.6 \mathrm{~b}$ & $48.5 \pm 0.5 \mathrm{~b}$ \\
\hline Inpari 9 & RTV-inoculated & $20.0 \pm 2.3$ & $21.8 \pm 3.9$ & $34.7 \pm 5.5$ \\
& Un-inoculated & $24.5 \pm 0.5$ & $32.0 \pm 0.6$ & $42.5 \pm 0.5$ \\
\hline Inpari 7 & RTV-inoculated & $15.8 \pm 1.4 \mathrm{a}$ & $18.2 \pm 1.2 \mathrm{a}$ & $26.1 \pm 4.9 \mathrm{a}$ \\
& Un-inoculated & $25.0 \pm 0.6 \mathrm{~b}$ & $32.5 \pm 0.5 \mathrm{~b}$ & $46.5 \pm 0.5 \mathrm{~b}$ \\
\hline
\end{tabular}

Values for RTV-inoculated and uninoculated plants of the same variety at the same observation day followed by different letters are significantly different at 0.05 .

DAI = Days after inoculation.

For GLH-resistant cultivars: plant height reductions on IR-46, Ciliwung, IR-64, and IR-66 were not significantly lower than the plant height reduction on TN-1 (susceptible control) during the three observation dates (14, 21 and 28 DAI) (Fig. 1A). One of the GLH-resistant cultivars, Ciliwung, even consistently suffered the most

severe height reductions in comparison to other cultivars during the study. This cultivar had 20, 21 and 3.8\% of height reduction over plant height reduction of TN-1 on 14, 21 and 28 DAI, respectively. While, IR-46 and IR-66 had the lowest height reductions, though they were not significantly lower than the height reduction in TN-1.

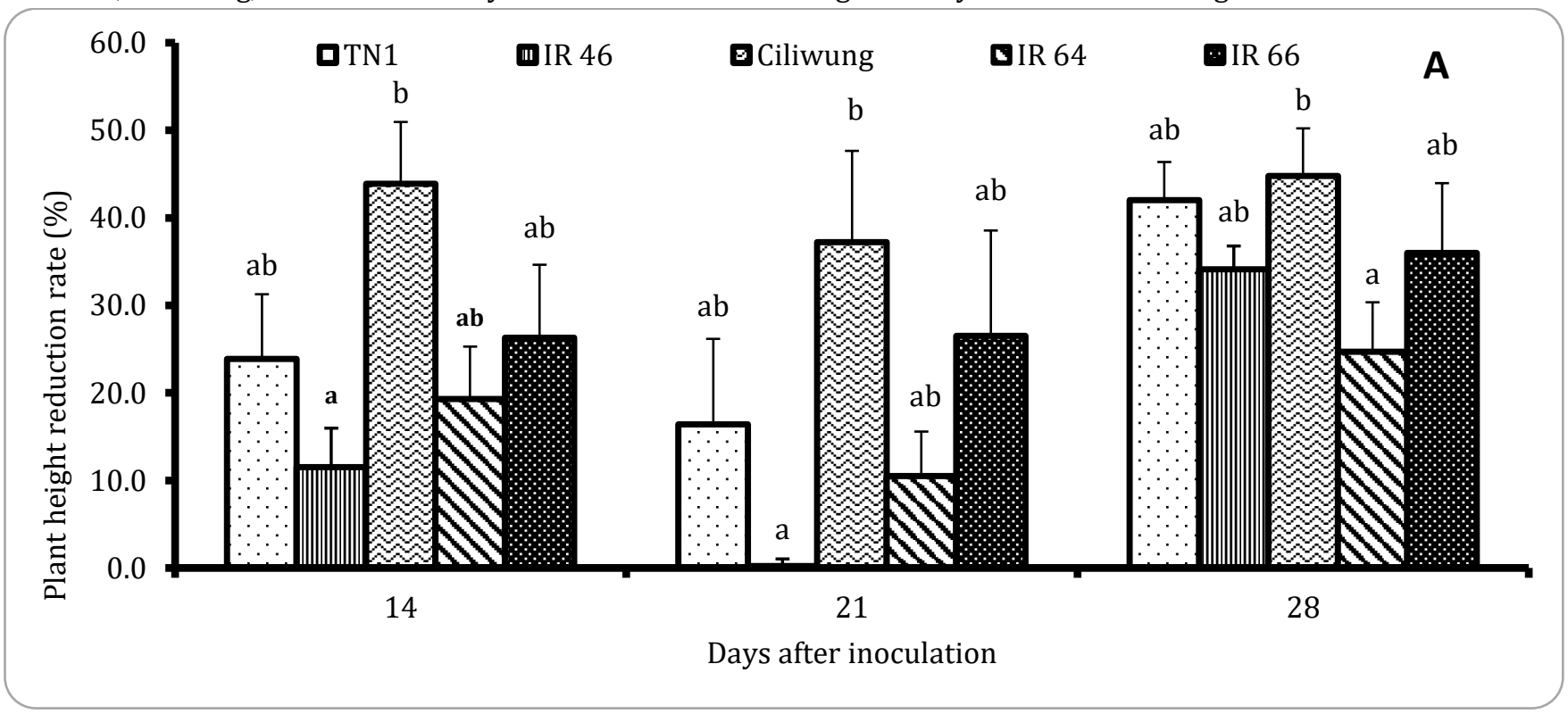




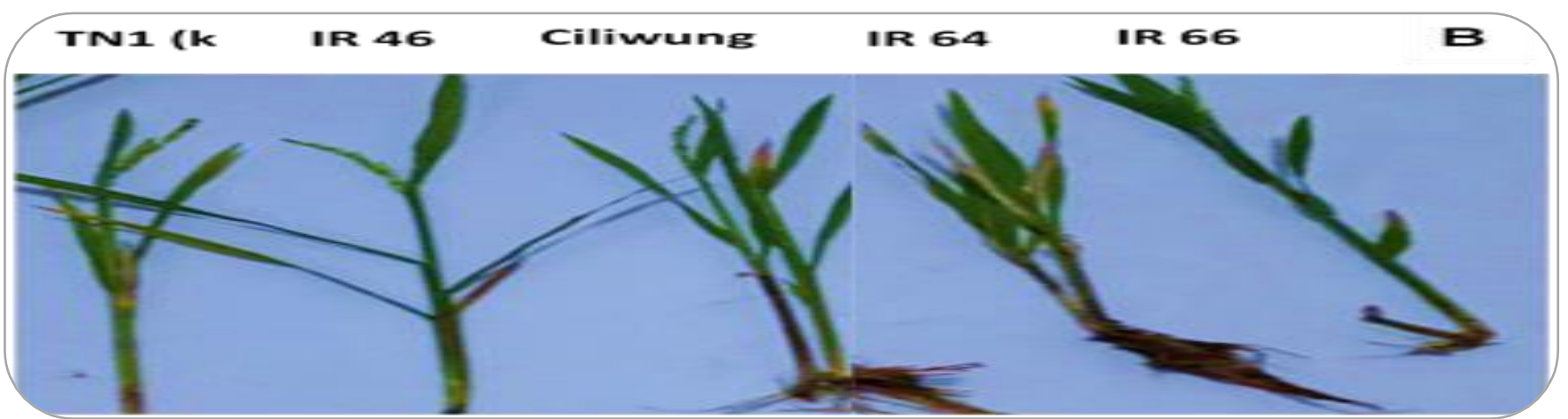

Figure 1. Plant height reduction in several GLH-resistant varieties infected by RTV. (A) Means ( \pm SE) with different letters at the same observation day are not significantly different ( $P=0.05$, Tukey's test). (B) Several GLHresistant varieties at 28 DAI with RTV.

For tungro-resistant cultivars, Tukad Balian and Inpari 99 was significantly lower than in TN-1. However, plant consistently had the lowest percent of plant height reduction amongst the tested cultivars (Fig. 2A). At 14 DAI, height reduction in Tukad Balian was significantly lower than in TN-1; similarly, height reduction in Inpari height reduction in Tukad Unda were higher and not significantly different from TN-1. Other cultivars were lower but not significantly different from TN-1 in plant height reduction throughout the experiment.
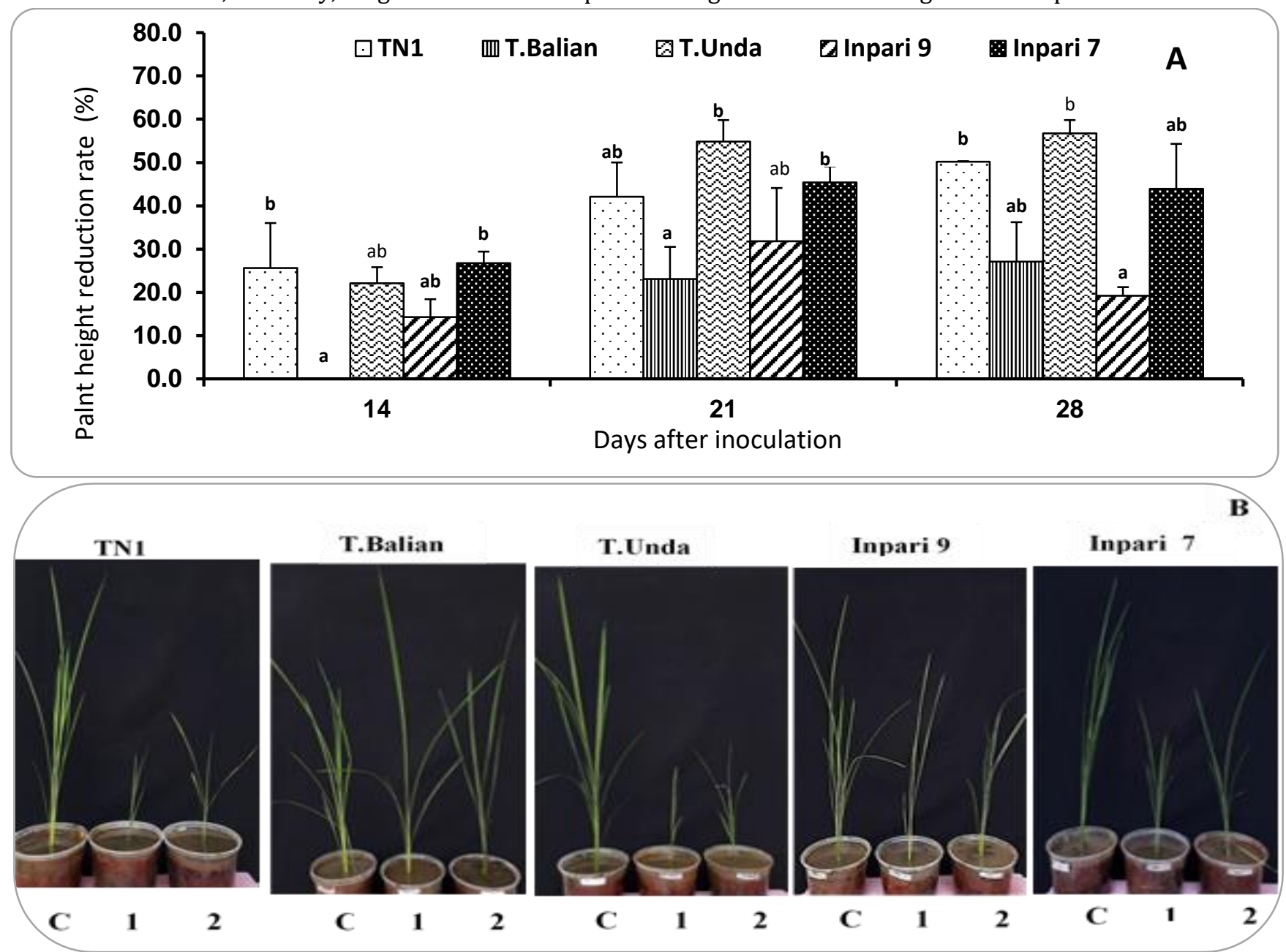

Figure 2. Plant height reduction in several tungro-resistant varieties infected by RTV. (A) Means ( \pm SE) with different letters at the same observation day are not significantly different $(P=0.05$, Tukey's test). (B) Several tungro-resistant varieties at 28 DAI with RTV. 
Percentage of RTV infection: The results of RTV inoculation showed that all GLH resistant varieties and RTV resistant varieties were infected by RTV with the Table 2. Response of GLH-resistant varieties and RTV-res

$\begin{array}{cr}\text { GLH-resitant varieties } & \text { Percentage of Infe } \\ \text { TN1 (no resistant gene) } & 100.0 \mathrm{~b} \\ \text { IR } 46 & 100.0 \mathrm{~b} \\ \text { Ciliwung } & 100.0 \mathrm{~b} \\ \text { IR } 64 & 80.0 \mathrm{ab} \\ \text { IR } 66 & 80.0 \mathrm{ab}\end{array}$

RTV-resistant varieties

TN1 ( no resistant gene )

Tukad Balian

Tukad Unda

Inpari 9

Inpari 7

$80.0 \mathrm{ab}$ percentages of infection ranging from 60.7 - 100\% which was not significantly different from TN1 (no resistance gene) and the reaction of the varieties was susceptible (Table 2). Varieties reaction Susceptible Susceptible Susceptible Susceptible Susceptible Varieties reaction Susceptible Susceptible Susceptible Susceptible Susceptible

Detection of RTBV and RTSV: RTBV-B2 F and RTBV-B2 R primers successfully amplified all RTBV coat protein genes with an amplicon of $430 \mathrm{bp}$ on all resistant varieties (IR 46, Ciliwung, IR64, IR 66, Tukad Balian, Tukad Unda, Inpari 9 Elo, and Inpari 7

$\begin{array}{cl}66.7 \mathrm{a} & \text { Susceptible } \\ 66.7 \mathrm{a} & \text { Susceptible } \\ 100.0 \mathrm{a} & \text { Susceptible } \\ 66.7 \mathrm{a} & \text { Susceptible } \\ 100.0 \mathrm{a} & \text { Susceptible }\end{array}$

Lanrang ) which was inoculated with RTV (Figure 3 and 4A). Whereas RTSV detection using RTSV-2F and RTSV-2R primers were only amplified on TN1, Tukad Balian, and Tukad Unda with a 787 bp amplicon (Figure 4B).

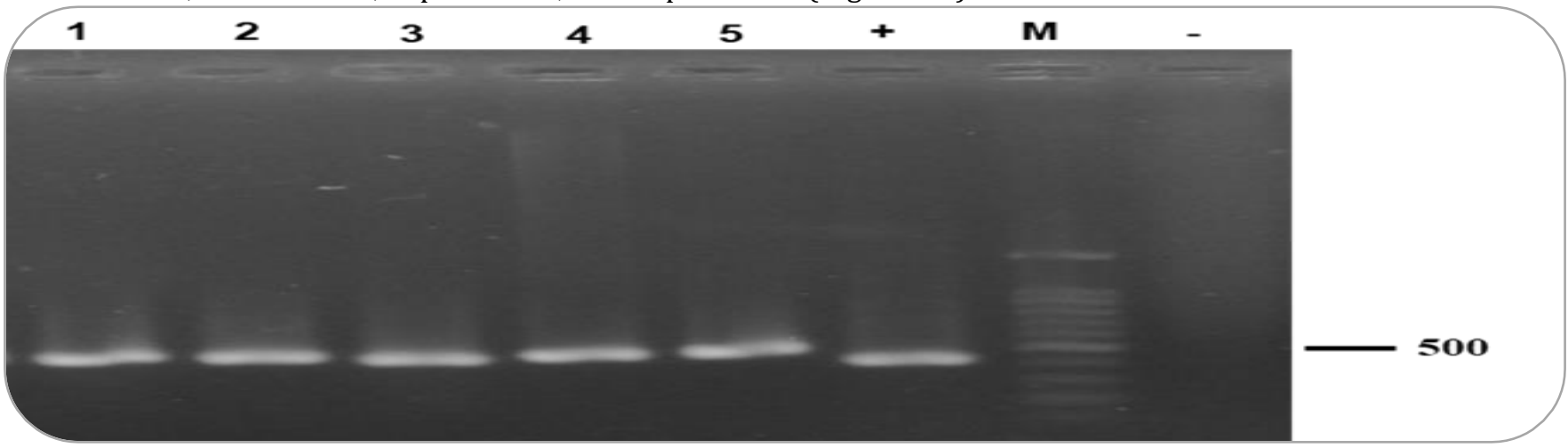

Figure 3. Amplification profiles of RTBV DNA bands of $430 \mathrm{bp}$ with RTBV-B2 F and RTBV-B2 R primers on GLHresistant plant that had been inoculated with RTV; $1=$ TN1, $2=\operatorname{IR~46,~} 3=$ Ciliwung, $4=\operatorname{IR~64,~} 5=$ IR 66, $+=$ positive control, M: 100 bp DNA ladder marker, and - : negative control.

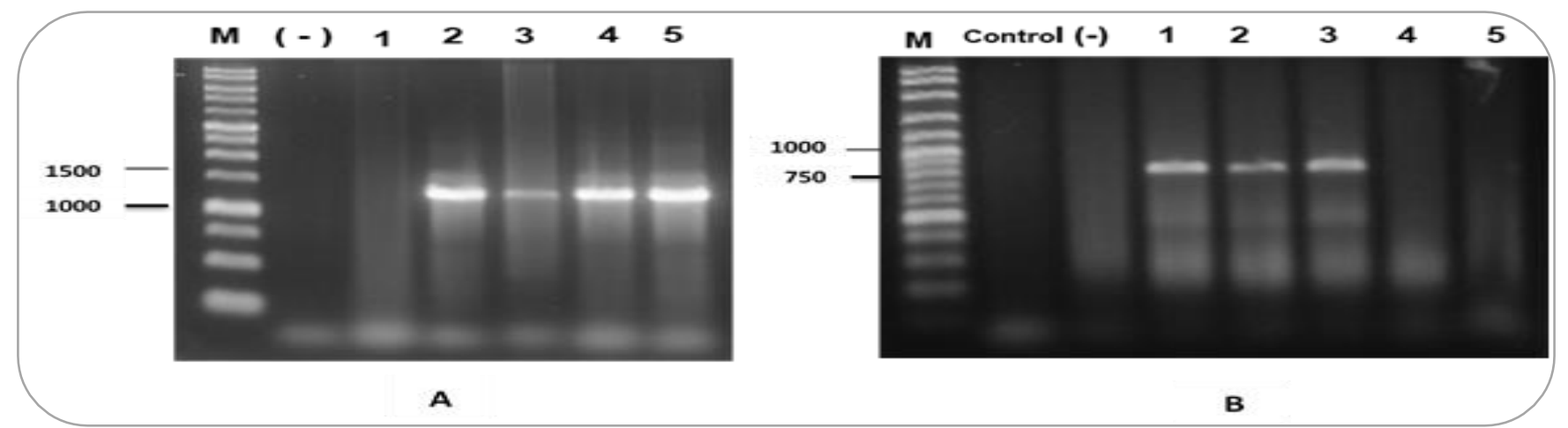

Figure 4. DNA amplification profiles on RTSV-resistant cultivars: A = RTBV DNA band of $1500 \mathrm{bp}$ amplified using RTBV-B2 F and RTBV-B2 R primers on plant cultivars inoculated with RTV, M: DNA ladder $1 \mathrm{~kb} . \mathrm{B}=\mathrm{RTSV}$ DNA bands of $787 \mathrm{bp}$ amplified using RTSV-F2 and RTSV-R2 primers on cultivars inoculated with RTV, $\mathrm{M}=$ DNA ladder 100 bp. - = negative control, $1=$ TN1, 2 = Tukad Balian, $3=$ Tukad Unda, $4=$ Inpari 9 Elo, $5=$ Inpari 7 Lanrang. 


\section{DISCUSSION}

The impacts of RTD infection to plant include reduced plant height or stunting. This trait can be used to evaluate resistance of certain cultivar against the virus (Calleja, 2010). A cultivar is considered resistance if the height of an RTD-inoculated plant is not significantly different from the height of the un-inoculated plant of the same cultivar. Furthermore, resistance can also be measured by comparing between the plant height reduction of certain cultivar and plant height reduction of a susceptible cultivar (TN-1, no resistance gene). The test cultivar is considered resistant if its height reduction is significantly lower than the height reduction of TN-1 due to RTV infection. In addition, cultivar resistance can also be evaluated by using percentage of infected plants of certain cultivar. The cultivar is categorized as resistant, moderately resistant, and susceptible if the infection rates are $0-30 \%,>30-$ $60 \%$, and $60-100 \%$, respectively (Azzam et al., 2000).

Our results indicated that for all GLH-resistant cultivars, plant heights of the inoculated plants were significantly lower than the un-inoculated plants of the same cultivar (Table 1). In addition, for each cultivar, percentage of plant height reduction was not significantly lower than the plant height reduction of the susceptible cultivar, TN-1 (Figure $1 \mathrm{~A}$ ). Furthermore, cultivar response test showed that percentages of infection of the inoculated plants were $100 \%, 100 \%, 80 \%$, and $80 \%$ for IR-46, Ciliwung, IR-64 and IR-66, respectively, which were categorized as susceptible cultivars (Table 2). These suggested that the resistant genes against the GLH in IR46, Ciliwung, IR-64, and IR-66 were no longer effective in controlling the GLH as the vector of RTV, hence impact of RTV infection on plant height reduction was not significantly lower than TN-1 (Table 1).

For the tungro-resistant cultivars, IR-46 and IR-66 showed that plants inoculated with RTD were significantly shorter than the un-inoculated plants of the same cultivar (Table 1). Besides that, plant height reductions of those cultivars were not significantly different from $\mathrm{TN}-1$. In addition, the results of the plant response test showed that both cultivars had 100\% RTD infection. Therefore, IR-46 and IR-66 were susceptible to RTD. On the other hand, Tukad Balian and IR-64 showed mixed results. Both cultivars showed no significant differences in plant height between RTDinoculated and un-inoculated plants of the same cultivar (Table 1). They also had percentages of plant height reduction that were significantly lower than the height reduction in $\mathrm{TN}-1$. However, the response test indicated that both cultivars were susceptible to RTD infection, with a rate of $66.7 \%$.

Based on the results of PCR analyses, both GLHresistant varieties were infected by RTBV in this study. it was found that all varieties that were resistant to GLH and those that were resistant to RTV had been infected by rice tungro bacilliform virus (RTBV). Since the cultivars have been cultivated continuously for many years in the area, the GLH has adapted to those cultivars; thus, it become effective vector of the virus (Sama et al. 1991). Widiarta et al., (2014) reported that green leafhoppers (GLH) were able to transmit the tungro virus (adaptive) to Ciliwung (Glh-6 resistant gene) and IR-64 (Glh 5 resistant gene) South Sulawesi. Tukad Petanu and Inpari 7 Lanrang were RTV-resistant varieties with a resistant gene source from Utri Merah (Kobayashi et al., 1993; Widiarta and Pakki, 2015; Khush et al., 2004). Utri Merah is known to be able to inhibit the development of RTBV particles (Hibino et al., 1978). After PCR testing, it turned out that both varieties were infected with RTBV. This may be due to a broken resistance system of the variety, as reported by Suprihanto et al. (2010) if several RTV-resistant varieties have caused symptoms of tungro disease. Only Inpari 9 Elo and Inpari 7 Lanrang have not been infected by rice tungro spherical virus (RTSV) (Figure $4 \mathrm{~b})$. RTSV has been considered a latent virus because the accumulation of RTSV alone does not cause recognizable symptoms in most rice genotypes (Oryza sativa). However, the lack of symptoms in RTSVinfected rice may be due to the activated defence mechanisms in rice, not due to a lack of pathogenicity in RTSV. RTSV itself induces significant changes in the expression of various genes associated with defence and development in O. sativa (Encabo et al., 2009; Satoh et al., 2013). Synchronization of RTSV and RTBV synergistically aggravates tungro symptoms in rice (Cabautan, et al., 1995). Despite the potential pathogenicity of RTSV accumulation, most of the 0 . sativa genotypes can share a species-specific tolerance mechanism that prevents them from being inhibited by RTSV (Budot et al., 2014).

\section{CONCLUSION}

Based on the results of height reduction rates, percentage of infection, and detection results by PCR analyses, it was revealed that all resistant varieties were 
infected with RTBV and only Inpari 9 and Inpari 7 were not infected with RTSV. Thus, resistant varieties that can still be recommended for planting in South Sulawesi are Inpari 9 Elo and Inpari 7 Lanrang.

\section{ACKNOWLEDGEMENT}

We gratefully appreciate the Indonesian Agency Agricultural Research and Development Ministry of Agriculture for funding this study. We also extend our deepest gratitude to Mr. Yusran Arifin for his assistance in collecting experimental data.

\section{REFERENCES}

Angeles, E. and G. Khush. 1999. 38. A new gene for resistance to green leafhopper, Nephotettix virescens (Distant) in rice.

Angeles, E. and G. Khush. 2000. Genetic analysis of resistance to green leafhopper, Nephotettix virescens (Distant), in three varieties of rice. Plant breeding, 119: 446-448.

Athwal, D., M. Pathak, E. Bacalangco and C. Pura. 1971. Genetics of resistance to brown plant hoppers and green leaf hoppers in Oryza sativa L. 1. Crop Science, 11: 747-750.

Azzam, 0. and T. C. Chancellor. 2002. The biology, epidemiology, and management of rice tungro disease in Asia. Plant Disease, 86: 88-100.

Azzam, O., M. Arboleda, K. Umadhay, J. De los Reyes, F. Cruz, A. Mackenzie and K. McNally. 2000. Genetic composition and complexity of virus populations at tungro-endemic and outbreak rice sites. Archives of virology, 145: 2643-2657.

Azzam, O., T. Imbe, R. Ikeda, P. Nath and E. Coloquio. 2001. Inheritance of resistance to rice tungro spherical virus in a near-isogenic line derived from Utri Merah and in rice cultivar TKM6. Euphytica, 122: 91-97.

Budot, B. O., J. R. Encabo, I. D. V. Ambita, G. A. AtienzaGrande, K. Satoh, H. Kondoh, V. J. Ulat, R. Mauleon, S. Kikuchi and I.-R. Choi. 2014. Suppression of cell wall-related genes associated with stunting of Oryza glaberrima infected with Rice tungro spherical virus. Frontiers in microbiology, 5: 1-9.

Bunawan, H., L. Dusik, S. N. Bunawan and N. M. Amin. 2014. Rice tungro disease: From identification to disease control. World Applied Sciences Journal, 31: 12211226.

Cabauatan, P. and H. Hibino. 1988. Isolation, purification, and serology of rice tungro bacilliform and rice tungro spherical viruses. Plant Disease, 72: 526-528.

Cabauatan, P., R. Cabunagan and H. Koganezawa. 1995.
Biological variants of rice tungro viruses in the Philippines. Phytopathology, 85: 77-81.

Calleja, D. 0. 2010. Water shortage due to El Nino breeds 'tungro' in rice plantations. Retrieved from http://balita.ph/2010/02/17/tungro-rice-diseasealert-up-in-bicol.

Choi, R. 2004. Current status of rice tungro disease research and future program. Strategi Pengendalian Penyakit Tungro: Status dan Program. Prosiding Seminar Nasional Status Program Penelitian Tungro Mendukung Keberlanjutan Produksi Padi Nasional. Makassar. pp. 7-8.

Chong, J., S. Yee and L. Eng. 2015. Rice Tungro Disease in Sarawak: past and present status. Pakistan Journal of Biological Sciences, 18: 285-289.

Doyl, J. and J. Doyle. 1990. Isolation of plant DNA from fresh tissue. Focus, 12: 13-15.

Encabo, J. R., P. Q. Cabauatan, R. C. Cabunagan, K. Satoh, J.-H. Lee, D.-Y. Kwak, T. B. De Leon, R. J. A. Macalalad, H. Kondoh and S. Kikuchi. 2009. Suppression of two tungro viruses in rice by separable traits originating from cultivar Utri Merah. Molecular plant-microbe interactions, 22: 1268-1281.

Hibino, H. 1996. Biology and epidemiology of rice viruses. Annual review of phytopathology, 34: 249-274.

Hibino, H., M. Roechan and S. Sudarisman. 1978. Association of two types of virus particles with penyakit habang (tungro disease) of rice in Indonesia. Phytopathology, 68: 1412-1416.

Hull, R. 1996. Molecular biology of rice tungro viruses. Annual review of phytopathology, 34: 275-297.

Karim, A. R. and M. Pathak. 1982. New genes for resistance to green leafhopper, Nephotettix virescens (Distant) in rice, Oryza sativa L. Crop Protection, 1: 483-490.

Karim, A. R. and M. Pathak. 1982. New genes for resistance to green leafhopper, Nephotettix virescens (Distant) in rice, Oryza sativa L. Crop Protection, 1: 483-490.

Khwabe, S. K. 1985. Mechanism of varietal resistance to the rice green leafhopper (Nephotettix cincticeps Uhler). Jarq, 19: 115-124.

McCouch, S., L. Sebastian, R. Ikeda, N. Huang, T. Imbe and W. Coffman. 1996. Molecular mapping of resistance to rice tungro spherical virus and green leafhopper. Phytopathology, 86: 25-30.

McCouch, S., L. Sebastian, R. Ikeda, N. Huang, T. Imbe and W. Coffman. 1996. Molecular mapping of resistance to rice tungro spherical virus and green leafhopper. Phytopathology, 86: 25-30. 
Nobuya, K., R. Ikeda and D. A. Vaughan. 1993. Resistance to rice tungro viruses in wild species of rice (Oryza spp.). Japanese Journal of Breeding, 43: 247-255.

Sama, S., A. Hasanuddin, I. Manwan, R. Cabunagan and H. Hibino. 1991. Integrated management of rice tungro disease in South Sulawesi, Indonesia. Crop Protection, 10: 34-40.

Satoh, K., H. Kondoh, T. B. De Leon, R. J. A. Macalalad, R. C. Cabunagan, P. Q. Cabauatan, R. Mauleon, S. Kikuchi and I.-R. Choi. 2013. Gene expression responses to Rice tungro spherical virus in susceptible and resistant near-isogenic rice plants. Virus research, 171: 111-120.

Sebastian, L., R. Ikeda, N. Huang, T. Imbe, W. Coffman, M. Yano, T. Sasaki and S. McCouch. 1996. Genetic mapping of resistance to rice tungro spherical virus (RTSV) and green leafhopper (GLH) in ARC11554,
Rice Genetics III: (In 2 Parts). World Scientific, pp. 560-564.

Siwi, B. H. and G. S. Khush. 1977. New Genes for Resistance to the Green Leafhopper in Rice 1. Crop Science, 17: 17-20.

Suprihanto, S., E. Nurhayati and J. Harjosudarmo. 2013. Virulensi Isolat Rice tungro virus dari Beberapa Daerah Endemis Tungro di Indonesia. Jurnal Fitopatologi Indonesia, 9: 29.

Wahab, M. I., Satoto, R. Rachmat, A. Guswara and Suhana. 2017. Deskripsi varietas unggul baru padi. Badan Penelitian dan Pengembangan Pertanian. Kementerian Pertanian. pp 87.

Widiarta, I. N., D. Kusdiaman, S. S. Siwi and A. Hasanuddin. 2017. Varian efikasi penularan tungro oleh kolonikoloni wereng hijau Nephotettix virescens distant. Jurnal Entomologi Indonesia, 1: 50.

\section{Contribution of Authors:}

Nur Rosida

Tutik Kuswinanti

Nur Amin

Andi Nasruddin
: Conduct research and wrote manuscript

: Review manuscript

: Edited manuscript and technical assistance

: Help in data interpretation, 